\title{
MANAGEMENT OF INFORMATION IN ECONOMIC DIPLOMACY
}

\author{
Marek Csabay $^{1}$ (D)
}

DOI: https://doi.org/10.31410/ITEMA.2019.135

\begin{abstract}
With regard to diplomacy information of various kind are in the very center of its operation and at the same time the purpose of existence. The paper discusses from the theoretical perspective the process of information management in economic diplomacy. The author shortly identifies the mandate of economic diplomacy in processing information based on the Vienna Convention on Diplomatic Relations from 1961 and focuses on the basic description of main information processes that take place within economic diplomacy. Part of the paper also discusses the role of information in diplomacy through areas of diplomatic action that may benefit from the information processes as well as their main receiving bodies.
\end{abstract}

Keywords: Economic Diplomacy, Management, Information Processes.

\section{INTRODUCTION}

$\mathrm{D}^{\mathrm{i}}$ iplomacy does not have a generally accepted theoretical definition, although its nature as a traditional means of conducting international relations through diplomatic agents is universally recognized not only by both academic and non-academic resources but also by norms of international public law. International relations include economic affairs among states; thus, we may speak of economic diplomacy as a means of their facilitation.

It is important to admit that the practice of economic diplomacy has many variations with some of them based more on customary praxis and acceptance by the receiving state than by strict interpretation of the Vienna Convention on Diplomatic Relations. Moreover, economic diplomacy is frequently used as a synonym or portrayal of actions by states that would seem to be better described as parts of international economic relations (e.g. exports, imports, investments), trade policy (e.g. application of some trade-political instrument) or other external economic policy while safeguarding economic interests abroad.

All of the above-mentioned areas of external economic activity have one aspect in common and that is their significant reliance on accurate, timely and exact information. Diplomacy is by its nature a mediator and processor of information. It collects and distributes information while exercising its tasks as an observing, negotiating and reporting arm of the government abroad.

\section{DEFINITION OF ECONOMIC DIPLOMACY}

Before we proceed to a further elaboration on information management processes in economic diplomacy, we have made a brief stop at its definition in order to establish a clear framework for the purposes of this paper. As mentioned already above, the term economic diplomacy is often generally used in a broader meaning that covers not only international exchange of goods and

Institute of International Business, Faculty of Economics and Business, Pan-European University, Tematinska 10, 85235 Bratislava, Slovak Republic 
services but also other components of international economic relations including international movement capital and labor as well as activities leading to coordination or adoption of economic policies. In a narrower and in our opinion more appropriate sense it is a part of public service, a government body established abroad based originally on customary practice and later on written sources of international law in a form of a foreign service governed by a domestic body, usually a ministry of foreign affairs or, eventually, a ministry responsible for external economic relations.

Various definitions can be demonstrated by following selected approaches, which of course do not represent a complete and comprehensive overview of authors dealing with this issue. Bayne and Woolcock (2004) and Okano-Heijmans (2011) hold that economic diplomacy deals with international economic relations. As Woolcock states (2013), economic diplomacy may be defined by the decision-making process and negotiations in international economic relations "in core issues such as trade, investment and finance... also included are topics, such as the environment and development, that have considerable economic implications for policies in that areas". These authors refer to trade, commercial, financial, investment and environmental diplomacy as specific forms of economic diplomacy.

The use of various other economic adjectives forms another element for understanding contemporary economic diplomacy. Historically, the first on the scene was the trade diplomacy aiming to promote the development of bilateral commercial relations and protect the commercial interests abroad. As Carron de la Carrière (1998) states just at the beginning of his renowned work: 'la diplomatie économique était autrefois tout simplement une diplomatie commerciale'. We may find several similar statements commenting on importance of cross-border entrepreneurial relations in diplomacy and vice versa elsewhere: commerce was 'a traditional interest of diplomacy' (Barston, 2006) and 'the importance of diplomacy for business has always been emphasised' (Hamilton and Langhorne, 1995).

Slovak school of economic diplomacy based on works by Tóth (1994), Tóth and Horváthová (2006) or Csabay (2019) tends towards a narrower definition of economic diplomacy as a specific type of civil service, activity of state bodies responsible for international economic relations and their representatives in representing the country vis-à-vis other countries focusing on the achievement of goals and tasks of the country's external economic policy through negotiations and by other legitimate means. With a general approach of this paper established by the before-mentioned definition we abstract from authors dealing with specific sectoral types of economic diplomacy, e.g. commercial diplomacy, trade diplomacy, investment diplomacy or innovations diplomacy (i. a. van Bergeijk, 2009, Ruël, 2012, Naray, 2008 and others) in further discussion due to the limitations of this paper.

\section{ROLE OF INFORMATION IN ECONOMIC DIPLOMACY}

As already indicated in the text above, the core of diplomatic activities resides in areas related to information and their processing. The mandate in this regard can be found in the wording of the Article 3 of the Vienna Convention on Diplomatic Relations from 1961, which states that the functions of a diplomatic mission consist, inter alia, in:

a) Representing the sending State in the receiving State;

b) Protecting in the receiving State the interests of the sending State and of its nationals, within the limits permitted by international law; 
c) Negotiating with the Government of the receiving State;

d) Ascertaining by all lawful means conditions and developments in the receiving State, and reporting thereon to the Government of the sending State;

e) Promoting friendly relations between the sending State and the receiving State, and developing their economic, cultural and scientific relations.

Especially the third, fourth and eventually the fifth point shall be regarded as the ground for gathering, processing and presenting of information of various kind related to inter-state relations. Information exchange is the essence of cooperative behavior in international relations materialized in existence of diplomacy. With regard to economic diplomacy this stands in no lesser extent than it is valid for political diplomacy.

Cooperative behavior exercised by economic diplomacy may acquire various forms: it can be observed in networking and liaising activities of diplomats, consultations, negotiations, reporting, creation of informal and binding regulations, etc. Networking of diplomats is a major vehicle of economic diplomacy, providing room for getting and keeping in contact with partners as well as exchanging information. Moreover, networking is a way of informally influencing the decisions made by partners and building positions for negotiations that might follow. Progress in promoting economic interests and addressing the issues resulting from economic relations between countries is made rather by applying cooperation methods than by applying a confrontational approach (Csabay, 2014).

The use of information in economic diplomacy on both macro (i.e. affecting the business environment like setting rules and regimes, negotiating treaties) and micro (i.e. affecting the individual companies or business cases) levels of action is similarly variable as the mentioned forms of diplomatic activity. It spreads from a simple transfer of raw information eventually even to a sophisticated consultancy, in particular it may receive a form of:

- Providing information;

- Promoting the country, industry or a particular company;

- Promoting the cooperation between businesses and matchmaking;

- Negotiation, lobbying, problem solving and conflict resolution including dispute settlement;

- Advisory and consulting services to government, industries or individual companies;

- Education and training.

In particular, the use of information related to different areas of action exercised by economic diplomacy is more closely explained in Table 1 .

Table 1. Use of information in various areas of diplomatic action

$\begin{array}{ll}\text { Area of Action } & \text { Role of Economic Diplomacy } \\ \text { Reporting } & \begin{array}{l}\text { Providing up-to-date, detailed, timely and accurate information for relevant recipients } \\ \text { on macro and micro levels that is necessary for the success of external economic } \\ \text { operations. }\end{array} \\ \text { Promotion } & \begin{array}{l}\text { Nation branding and creating goodwill and positive image of the country or industry. } \\ \text { Organising national or industrial presentations and providing support and assistance for } \\ \text { companies at international fairs and exhibitions abroad. }\end{array} \\ \text { Cooperation } & \begin{array}{l}\text { Matchmaking and promoting of other means of contact development, organizing } \\ \text { business missions, economic workshops, negotiating and assisting in negotiations, } \\ \text { organizing and participating in social events, diplomatic entertaining. }\end{array}\end{array}$




$\begin{array}{ll}\text { Area of Action } & \text { Role of Economic Diplomacy } \\ \text { Negotiation } & \begin{array}{l}\text { Negotiation in the narrow sense, exercising influence on the decision-making process of } \\ \text { relevant foreign institutions in order to achieve or enhance benefits in accordance with } \\ \text { the country's economic interests, solving of problems in economic relations, dispute } \\ \text { settlement and conflict resolution in general on both macro- and micro-economic level. }\end{array} \\ & \begin{array}{l}\text { Providing advice on specific questions of external economic relations on both macro- } \\ \text { and micro-economic level, incl. advisory and consultancy to government bodies, } \\ \text { industries, providing basic advice to companies in the process of establishing and } \\ \text { Consulting }\end{array} \\ \text { Education } & \text { Participation in territorially focused business seminars and training of diplomatic staff. }\end{array}$

Source: author

\section{4, INFORMATION PROCESSES IN ECONOMIC DIPLOMACY}

The prevailing part of diplomatic activities in the field of economic diplomacy - whether protection of state economic interests, representation and representation of the state, preparation of negotiations and negotiations with foreign partners, creation of international regime and rules, lobbying, conflict and problem solving, promotion, training activities, counseling and messaging - they take place within two basic and traditional categories of diplomatic activities that are closely interrelated: networking activities (or liaising) and reporting activities (or intelligence).

Diplomatic networking can be described as a contact with foreign and domestic partners, which are relevant for the fulfillment of the objectives of economic diplomacy. Exercising economic diplomacy in a foreign territory usually requires meeting with three categories of partners:

- officials and public servants of the receiving state,

- members of the diplomatic corps in the country of accreditation,

- representatives of the private (business) sphere.

Within the diplomatic mission, there is a natural division of labor between its members, depending on their status. Part of the networking activity of economic diplomacy is covered by the head of the mission (ambassador), e.g. in relation to the heads of state or government and members of the government. Lower levels shall be covered by delegated staff, either in their particular capacity giving them responsibility for a certain area of economic affairs or based on an instruction from the head of the mission. In addition to obligatory contacts with representatives of ministry of foreign affairs of the receiving state, the former case includes mostly representatives of economic ministries, specialized government agencies (trade promotion organizations, export credit agencies, etc.), customs authorities, standardization bodies and other relevant institutions. Representatives of international economic organizations may also be included in this category.

The partners in the accredited diplomatic corps are, according to the appropriate level, the other heads of diplomatic missions or economic diplomats. Partners from the private sector form a relatively heterogeneous group, ranging from business associations and economic, industrial or trade chambers through financial institutions, economic think-tanks, exhibition centers, convention centers and media companies to individual entrepreneurs active in business with the diplomat's home country.

Networking activities take place in formal environments such as meetings, workshops, conferences, seminars, exhibitions, etc., but also in informal social events, which are inherently part of diplomacy. 
An important point is that a similar extent of contacts must be developed by economic diplomacy not only in the country of operation, but also at home in the sending state since both represent a source of impulses for its activities and - more importantly - a list of potential recipients of its outputs.

Establishing contacts in the three above-mentioned categories is one of the primary tasks that an economic diplomat must master. Contacts represent a primary, although not the only, source of information for an economic diplomat. The second main source is data and information contained in political and analytical documents, registers and databases. Since diplomacy as such, including its economic branch, is a system of handling information, together these two source groups represent inputs into the information processing (see Figure 1).

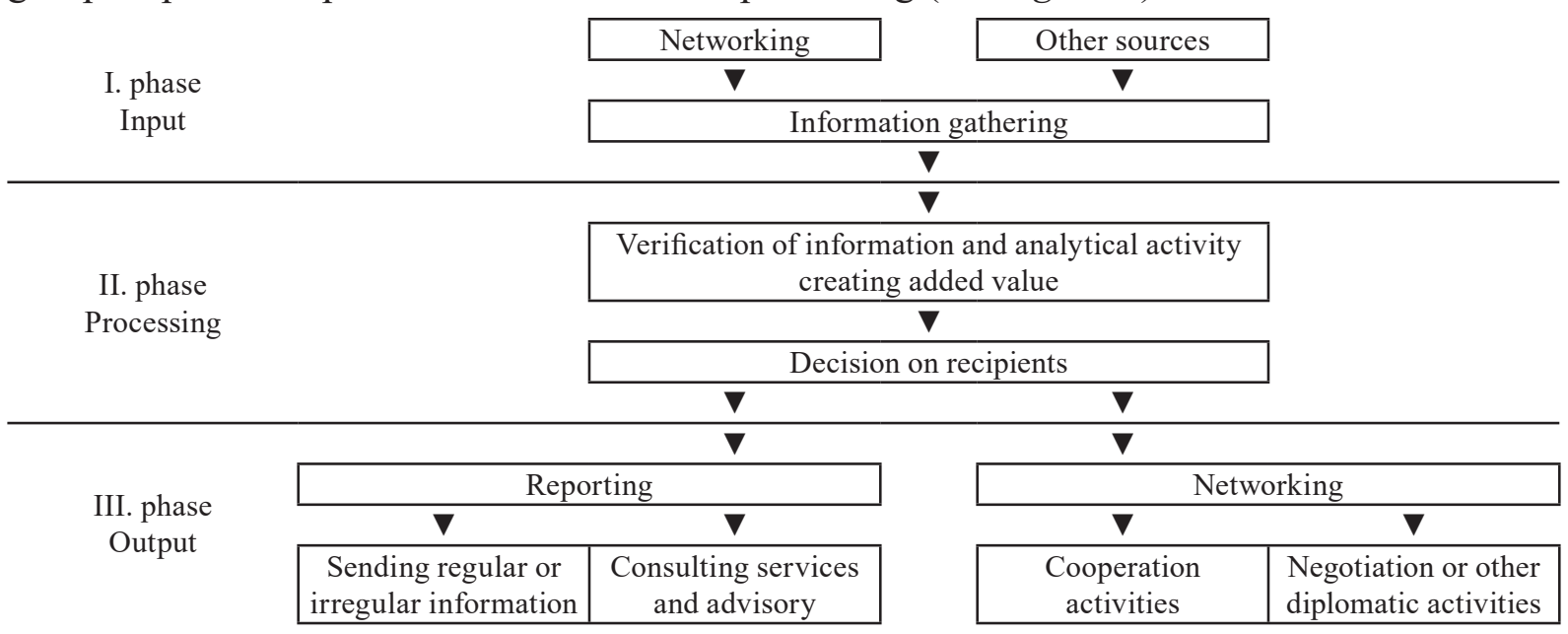

Figure 1. Economic Diplomacy as an Information Process

Source: author

The information process takes place according to the instructions that economic diplomacy fulfills in the territory of accreditation. Instructions set out the priorities that individual actors in foreign territories pursue - in some cases it may be a search for business or investment opportunities, in others, an establishment of a trade regime or other economic cooperation.

The first phase of the information process includes the collection of information from networking and other sources, i.e. it takes place as part of a routine activity, which is normally carried out by economic diplomacy in accordance with the instructions sent. The information process can also be initiated by a specific impulse from the domestic environment, either from the management department or from the business environment, from which economic diplomacy receives an inquiry. The range of information obtained by economic diplomacy is very diverse - from information on economic developments in the territory, on market developments, on prepared or implemented economic policies, changes in business legislation, through customs information, technical standards, sanitary and phytosanitary norms, import rules, demands and supplies, all the way to requests to verify information about potential and existing business partners.

The second phase is the process of verification and analytical evaluation of obtained information. While the first phase places requirements on the economic diplomat with regard to his / her communication and social skills, the second phase requires the ability of analytical and critical evaluation of the obtained information in relation to its content and source, and thus verification of its relevance, completeness, truthfulness and credibility. The aim of the analytical activity is to create added value resulting from the local expertise of the diplomat. On this basis, it is 
possible to make a decision on possible recipients of the information, unless they are determined on the basis of the instruction.

The list of recipients may include the head of the mission, headquarters (the respective ministry, its responsible managing unit or territorial desk), other state institutions or private sector entities. In the case of a decision on recipients of information containing business opportunities obtained by economic diplomacy through its own initiative (it means when not responding to a particular request from a particular company), transparency and equal opportunities between potential business beneficiaries must be strictly maintained. The usual procedure in such a case should be, if circumstances allow it, to give the information to a representative business association or a chamber rather than directly forward it to a particular entrepreneur.

The outcome of the information process is intelligence activity - reporting by means of sending regular and irregular information to the headquarters or to a designated recipient. The intelligence activity of economic diplomacy results either from the requirements defined in general instructions, or from the ad hoc requirements from the managing department or the business sphere, or - eventually - from the findings gathered on its own initiative. Regular reports include annual surveys of economic developments in the country or countries of operation, updates of the territory's basic information or an overview of major economic events (such as trade fairs, contracting B2B and B2G events, innovation and investment conferences, etc.). Irregular reporting includes i.e. information relevant for visits and negotiations by state officials and other information based on the requirements of state institutions as well as any business-related information intended for the private sector. In most cases, the output is either in form of sending information for further processing by the recipient or in form of formulating recommendations to the state authorities or consultancy services to the business sphere.

An alternative outcome of the information process is the follow-up networking in the form of cooperative events of different nature for state or private participants, eventually continuation of negotiations or other diplomatic activities in the never-ending cycle of gathering, processing and sending information through economic diplomacy as a negotiating arm of the state while fulfilling the tasks and objectives of the external economic policy.

\section{FUTURE RESEARCH DIRECTIONS}

The aim of the paper represented at the same time its most significant limitation - by describing the theoretical framework of the processing of information within and by the economic diplomacy it omitted a deeper analysis of its practical application. At the same time, this defines the area for possible future research of this topic e.g. by means of comparative analysis of practical application of various information processes and management of information flows in different national systems of economic diplomacy.

\section{CONCLUSION}

Economic diplomacy, as well as diplomacy in general, relies significantly on accurate, timely and exact information. Diplomacy is by its nature a mediator and processor of information. It collects and distributes information while exercising its tasks as an observing, negotiating and reporting arm of the government abroad. The article 5 of the Vienna Convention on Diplomatic Relations, which defines the functions of the diplomatic mission, forms the ground for gathering, processing 
and presenting of information of various kind related to inter-state relations. At the same time, we can state that information exchange is the essence of cooperative behavior in international relations.

The use of information in economic diplomacy on both macro (i.e. affecting the business environment like setting rules and regimes, negotiating treaties) and micro (i.e. affecting the individual companies or business cases) levels of action spreads from a simple transfer of raw information to a sophisticated consultancy, which may receive a form of providing information; promoting the country, industry or a particular company; promoting the cooperation between businesses and matchmaking; negotiation, lobbying, problem solving and conflict resolution including dispute settlement; advisory and consulting services to government, industries or individual companies; or even education and training.

As described in the last part of the paper, information management within the economic diplomacy takes place in three phases - information gathering from networking and other sources as an input into the system, information processing including the verification, evaluation and analysis of gathered information and reporting to various recipients from both public and private sector or other diplomatic activity as an output.

\section{ACKNOWLEDGMENT}

This research was supported by the Grant Agency Academia Aurea [GA/7/2019].

\section{REFERENCES}

Barston, R. P. (2006). Modern Diplomacy. Harlow: Pearson Education

Bayne, N. \& Woolcock, S., (2004). The New Economic Diplomacy: Decision Making and Negotiation in International Economic Relations. Hampshire: Ashgate

Van Bergeijk, P. A. G. (2009). Economic Diplomacy and the Geography of International Trade. Cheltenham: Edward Elgar Publishing Limited

Carron de la Carrière, G. (1998). La diplomatie économique: le diplomate et le marché. Paris: Economica

Csabay, M. (2014). Export-Promoting Policy and Economic Diplomacy: Contemporary Concepts and Instruments. In: Sipko, J., Dudáš, T. \& Csabay, M. (2014). International Economics and Finance. (pp. 82-149) Praha a Bratislava: Wolters Kluwer

Csabay, M. (2019). Ekonomická diplomacia. Teoretické východiská, riadenie a prax v medzinárodnom podnikaní. Bratislava: Wolters Kluwer

Hamilton, K. \& Langhorne, R. (1995) The Practice of Diplomacy. London: Routledge

Naray, O. (2008). Commercial Diplomacy: A Conceptual Overview, 7th World Conference of TPOs, The Hague

Okano-Heijmans, M. (2011). Conceptualizing economic diplomacy: the crossroads of international relations, economics, IPE and diplomatic studies. In: The Hague Journal of Diplomacy, Vol. 6, No. 1, pp.7-36

Ruël, H. (Ed.). (2012). Commercial Diplomacy and International Business. A Conceptual and Empirical Exploration. Bingley: Emerald Group Publishing Ltd.

Tóth, L. (1994). Protokol a etiketa v diplomacii a obchode. Bratislava: THB

Tóth. L. \& Horváthová. K. (2006). Hospodárska diplomacia. Bratislava: Sprint

Woolcock, S. (2013). Economic Diplomacy. In: Kerr, P. \& Wiseman, G. (Eds.): Diplomacy in a Globalizing World. Theories and Practices. (pp. 209-225) Oxford: Oxford University Press 